\title{
Penentuan Batas DAS Tojo Berbasis GIS Menggunakan Perangkat HEC HMS 4.4 dan QGIS 3.16
}

\author{
Aswar Amiruddin*1, Asta², Rosmalia Handayani ${ }^{3}$ \\ 1,2,3 Universitas Borneo Tarakan, Jalan Pantai Amal Lama No.1, Tarakan \\ ${ }^{1,2,3}$ Program Studi Teknik Sipil, Fakultas Teknik Universitas Borneo Tarakan, Tarakan \\ E-mail: *1aswaramir89@gmail.com
}

Received 06 November 2021; Reviewed 14 November 2021; Accepted 12 December 2021

Journal Homepage: http://jurnal.borneo.ac.id/index.php/borneoengineering

\begin{abstract}
Watershed delineation is the process of determining the area that contributes to flowing the rainfall into a runoff towards the outlet. The analysis of watershed delineation in this study used HEC-HMS version 4.4 and QGIS 3.16 software. HEC-HMS version 4.4 is equipped with the GIS tools that have been directly integrated therefore it can facilitate the watershed delineation process. The research area of the study is Tojo watershed which is located in Central Sulawesi. Digital Elevation Model(DEM) source data used in the study is DEMNAS BIG with a spatial resolution of $8,1 \mathrm{~m}$. The result indicates that the watershed delineation using HEC-HMS version 4.4 is similar to the watershed delineation of QGIS 3.16 software. There is a slight difference in the watershed's perimeter in several spots when it is zoomed in. The width of the watershed determined by both software is 212,583 $\mathrm{km}^{2}$ for HEC-HMS and 212,5404 $\mathrm{km}^{2}$. The HEC-HMS version 4.4 gives well enough results in analyzing Tojo watershed's perimeter, therefore it can also be used in other researches related to water resources.
\end{abstract}

Keywords: HEC-HMS 4.4, QGIS 3.16, Watershed delineation, GIS

\begin{abstract}
Abstrak
Delineasi DAS adalah proses penentuan wilayah atau kawasan yang berkontribusi mengalirkan hujan (presipitasi) menjadi aliran permukaan (runoff) pada satu titik luaran (outlet). HEC-HMS versi 4.4 memiliki perangkat GIS telah terintegrasi langsung sehingga memudahkan proses delineasi DAS. Analisis batas DAS pada penelitian ini menggunakan perangkat HEC-HMS versi 4.4 dan QGIS 3.16. HEC-HMS versi 4.4 memiliki perangkat GIS telah terintegrasi langsung sehingga memudahkan proses delineasi DAS. Daerah studi pada penelitian kali ini adalah DAS Tojo yang terletak di Provinsi Sulawesi Tengah. Sumber data Digital Elevation Model (DEM) yang digunakan adalah data DEMNAS BIG dengan resolusi spasial 8,1 $\mathrm{m}$. Hasil delineasi DAS dengan perangkat HEC-HMS 4.4 sama dengan hasil delineasi DAS menggunakan perangkat QGIS 3.16. Terdapat sedikit perbedaan garis batas DAS di beberapa bagian jika dilakukan pembesaran (zoom). Luas DAS yang dihasilkan masing-masing perangkat adalah HEC-HMS 212,583 $\mathrm{km}^{2}$, QGIS 212,5404 $\mathrm{km}^{2}$. Perangkat HEC-HMS 4.4 memberikan hasil yang cukup baik pada analisis batas DAS Tojo, sehingga perangkat HEC-HMS 4.4 ini juga dapat digunakan dalam penelitian-penelitian lainnya bidang sumber daya air.
\end{abstract}

Kata kunci: HEC-HMS 4.4, QGIS 3.16, Delineasi DAS, GIS 


\section{Pendahuluan}

Daerah Aliran Sungai atau yang disingkat DAS adalah daerah yang dibatasi oleh punggungpunggung pegunungan dimana air yang jatuh pada daerah tersebut akan mengalir menuju suatu titik yang ditinjau (Triatmodjo, 2013). Daerah Aliran Sungai (basin, drainage basin, cathment area atau watershed) menunjukkan suatu luasan yang berkontribusi pada aliran permukaan (Indarto, 2016). Setiap DAS, selain memiliki sifat-sifat yang khas, juga memiliki cakupan wilayah yang luas. Karena batasan wilayah suatu Daerah Aliran Sungai (DAS) yang luas, maka dalam menentukan batas DAS dan analisis komponen-komponen hidrologi DAS secara konvensional akan menimbulkan banyak kesulitan, sehingga diperlukan teknik pemodelan dengan memanfaatkan sistem informasi geografis (SIG) (Gunawan, 2011). Penggunaan Sistem Informasi Geografis (SIG) adalah metode yang sederhana dan akurat untuk pemodelan hidrologi dan sedapat mungkin dimanfaatkan dalam bidang rekayasa dan pengelolaan sumber daya air (Bhatt and Pandya, 2014; Al Amin, 2020).

Delineasi batas DAS adalah proses penentuan wilayah atau kawasan yang berkontribusi mengalirkan hujan (precipitation) menjadi aliran permukaan (surface runoff) pada satu titik luaran (outlet) (Purwono, 2018). Terdapat lima metode yang dapat digunakan dalam menentukan batas DAS. Pertama, penentuan batas DAS dengan bantuan peta RBI. Kedua, digitasi dari peta RBI dengan bantuan perangkat GIS. Ketiga, digitasi batas DAS dari peta Google Earth yang terlebih dahulu diregistrasi menggunakan perangkat GIS. Keempat, peta batas DAS digambar menggunakan kombinasi peta kontur dan jaringan sungai. Kelima, peta batas DAS diturunkan dari pengolahan data Digital Elevation Model (DEM) menggunakan perangkat GIS (Indarto, 2016). Dari kelima metode tersebut terdapat tiga metode yang memanfaatkan sistem informasi geografis atau yang lebih dikenal dengan GIS.

Ketelitian dari proses delineasi batas DAS dan analisis komponen-komponen hidrologi DAS lainnya melalui perangkat sistem informasi geografis (GIS) sangat dipengaruhi oleh tingkat akurasi dan resolusi dari data masukan utama yakni Digital Elevation Model (DEM), sehinga DEM yang digunakan pada proses delineasi DAS harus memiliki resolusi yang baik. Melalui proses pengolahan data DEM pada perangkat GIS, maka proses delineasi batas DAS dan analisis komponen-komponen hidrologi DAS menjadi lebih mudah. Komponen hidrologi DAS yang diperoleh melalui pengolahan data DEM pada perangkat GIS diantaranya arah pengaliran, akumulasi aliran, batas DAS, luas DAS, dan panjang sungai. Ketelitian pada proses penentuan batas (delineasi) DAS menjadi hal yang sangat penting dalam pengelolaan DAS. Hasil analisis dari proses delineasi DAS selanjutnya dapat digunakan untuk keperluan prediksi banjir rancangan (Strapazan and Petrut, 2017).

Perangkat Hydrologic Engineering Centre (HEC) merupakan perangkat pemodelan hidrologi yang dikembangkan oleh U.S. Army Corps of Engineers (USACE). Rilis pertama dari perangkat ini adalah versi 1.0 dan menyertakan sebagian besar kemampuan simulasi dari program HEC-1 (HEC-HMS User manual, 2021). USACE terus berinovasi dalam pengembangan HEC-HMS ini, banyak perbaikan dan penambahan fungsi-fungsi yang berguna dalam proses pemodelan hidrologi (Al Amin, 2020). Tahun 2003 USACE mengembangkan ekstensi HEC Geo-HMS. Ekstensi HEC Geo-HMS dapat digunakan untuk membuat model cekungan dan meteorologi yang dapat diaplikasikan bersama dengan perangkat ArcGIS. Selanjutnya USACE menambahkan tools GIS pada HEC-HMS versi 4.4, tools GIS ini telah terintegrasi langsung pada HEC-HMS 4.4 sehingga memudahkan proses delineasi DAS (HEC-HMS User manual, 2021). Hasil delineasi DAS dari perangkat HEC-HMS 4.4 sama dengan delineasi DAS menggunakan ArcGIS sehingga tingkat akurasi dan kualitas delineasi HECHMS 4.4 adalah sangat baik (Al Amin, 2020). 
Penelitian ini bertujuan untuk mengkaji proses-proses yang dijalankan oleh tools GIS pada setiap tahapan saat menjalankan delineasi DAS dan elemen-elemen model hidrologi yang terdapat pada perangkat HEC-HMS versi 4.4 dan QGIS 3.16 kemudian mengkaji perbedaan dari setiap tahapan tersebut.

\section{Metode Penelitian}

Penentuan batas DAS (delineasi DAS) pada penelitian ini menggunakan teknik analisis GIS. Delineasi DAS diproses menggunakan perangkat HEC-HMS versi 4.4 dan QGIS 3.16. Kedua perangkat yang digunakan pada penelitian kali ini, baik HEC-HMS 4.4 maupun perangkat QGIS 3.16 merupakan perangkat dengan lisensi sumber terbuka atau open source, yang dapat diperoleh melalui halaman web masing-masing pengembang perangkat.

Lokasi penelitian kali ini secara administratif terletak di Kabupaten Tojo, Provinsi Sulawesi Tengah yang berbatasan dengan Teluk Tomini di sisi utara, Kabupaten Morowali Utara di sisi selatan, Kabupaten Poso di sisi barat dan Kota Ampana di sisi timur (Amiruddin, 2020). Peta administrasi Kabupaten Tojo Una Una dapat dilihat pada Gambar1.

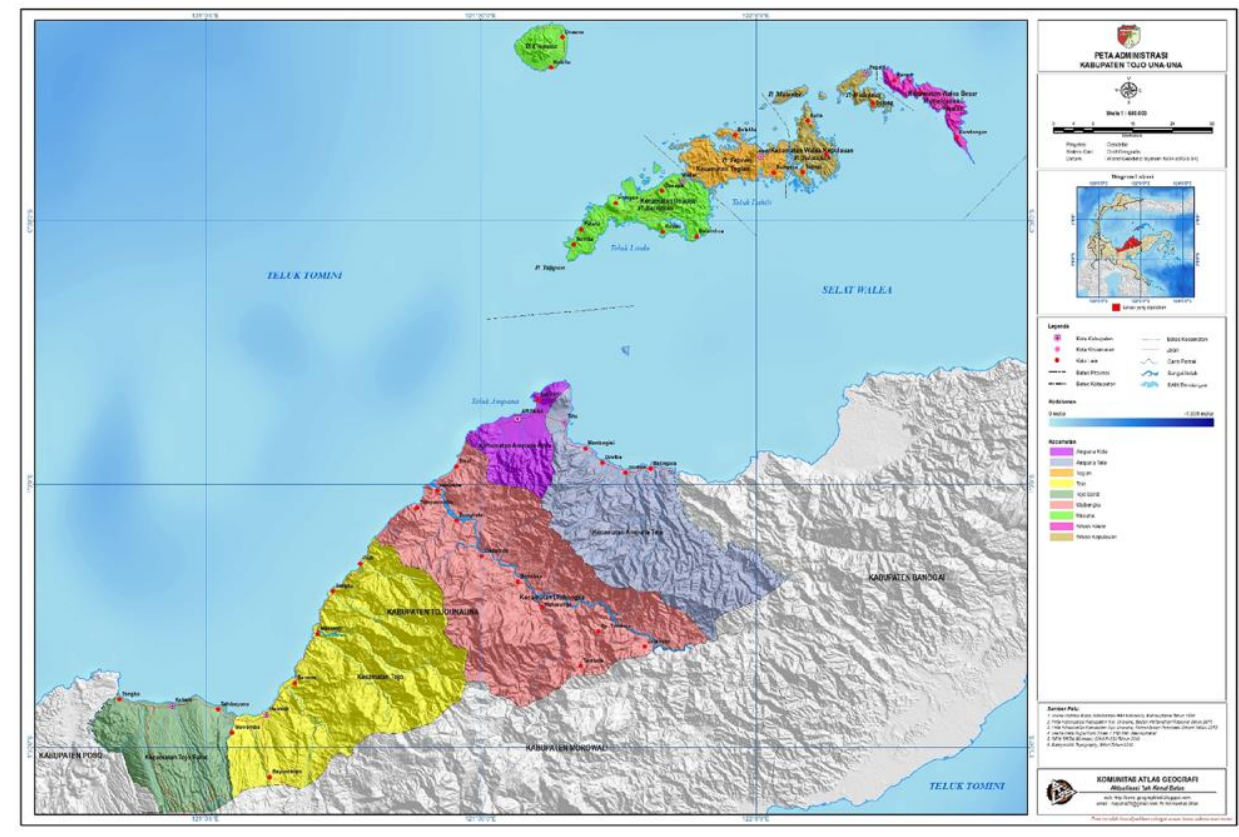

Gambar 1. Peta Administrasi Kabupaten Tojo Una-Una

(sumber : https://tojounauna.go.id/images/Peta/petaa.png)

Data DEM yang diproses pada kedua perangkat untuk melakukan delineasi DAS merupakan data DEM yang bersumber dari data Digital Elevation Model Nasional (DEMNAS) Badan Informasi Geospasial (BIG). Data DEMNAS ini merupakan hasil dari gabungan beberapa sumber data, terdiri dari IFSAR (Interferometric Synthetic Aperture Radar) yang memiliki resolusi 5 m, TERRASAR-X resolusi $5 \mathrm{~m}$ dan ALOS PALSAR (Advanced Land Observing Satellite - Phased Array type L-band Synthetic Aperture Radar) dengan resolusi 11,25 m. Resolusi spasial DEMNAS adalah 0,27arcsecond atau sama dengan 8,1 m. Datum vertikal DEMNAS adalah EGM2008 (Earth Gravitational Model 2008). DEMNAS yang digunakan pada proses delineasi DAS pada penelitian kali ini dapat dilihat pada Gambar 2. 
Proses pengolahan data DEMNAS sebagai masukan utama penelitian delineasi DAS ini dimulai dengan mendownload peta DEMNAS lokasi sekitar DAS Tojo sebanyak 16 nomor lembar peta (NLP) seperti yang ditunjukkan pada Gambar 3. Proses selanjutnya adalah mengolah data DEMNAS yang telah didownload, yakni melakukan penggabungan (mosaic) 16 Nomor Lembar Peta (NLP) melalui perangkat GIS untuk memperoleh data DEMNAS yang mengcover keseluruhan wilayah lokasi penelitian, kemudian menyesuaikan sistem proyeksi DEM tersebut menjadi UTM (universal transverse mercator) Zona 51S. Sistem koordinat UTM merupakan proyeksi yang detail dan bersifat lokal dengan satuan meter. Sistem koordinat UTM merupakan sistem koordinat dunia yang dibagi menjadi zona-zona dengan jumlah 60 zona dengan interval $6^{\circ}$ (Hasna, dkk. 2018). Selanjutnya data DEM yang telah diolah dapat diproses pada delineasi DAS menggunakan perangkat HEC-HMS 4.4 dan Qgis 3.16.

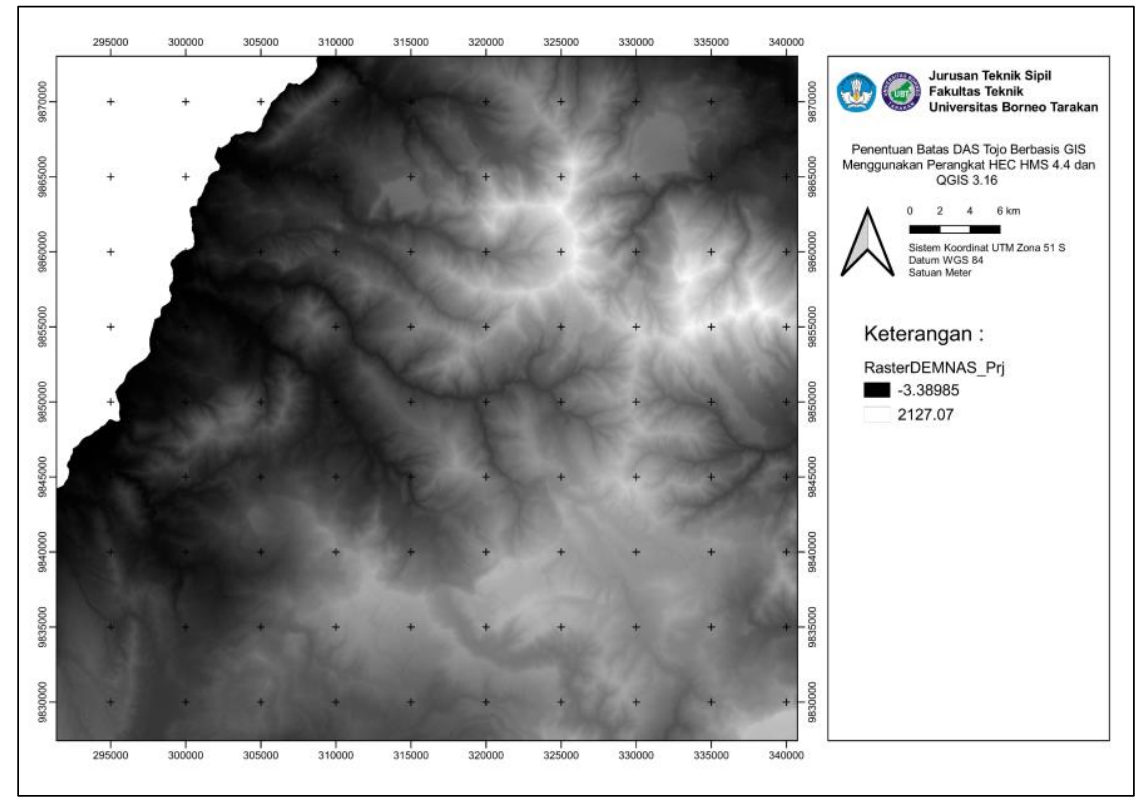

Gambar 2. Data DEMNAS

(sumber : https://tanahair.indonesia.go.id/demnas/\#/)

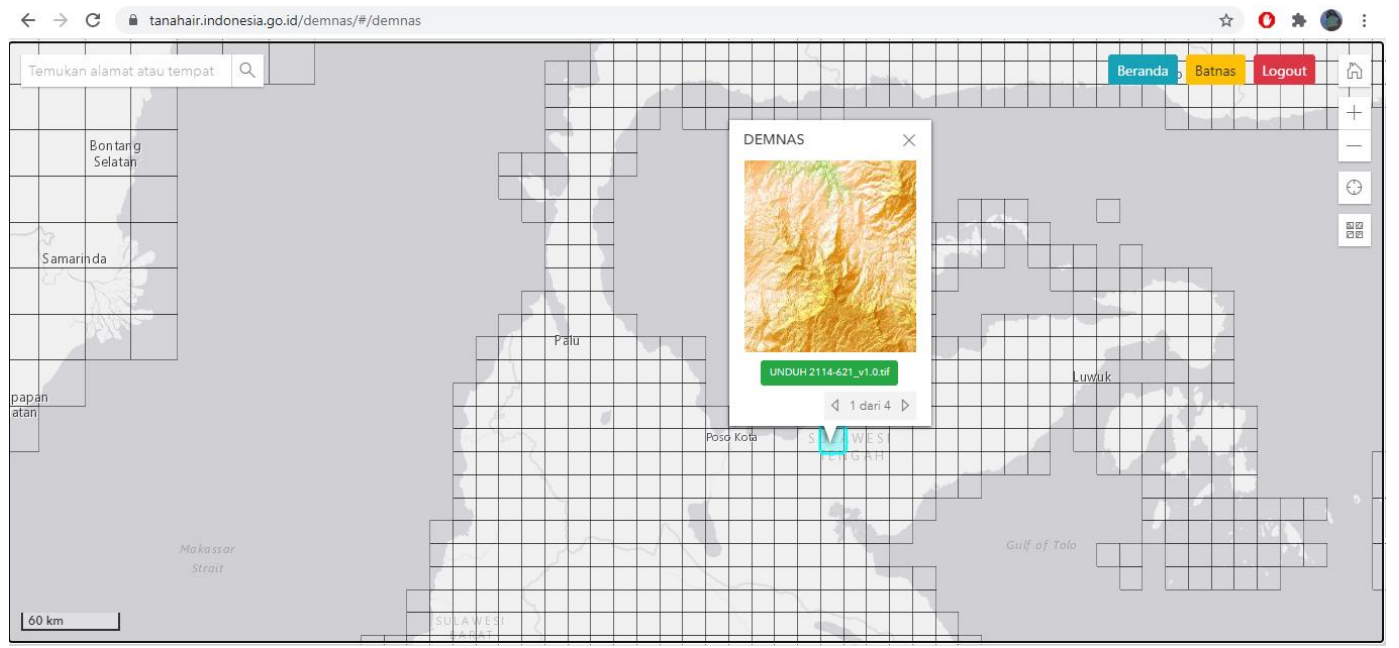

Gambar 3. Tampilan Sumber Data DEMNAS

(sumber : https://tanahair.indonesia.go.id/demnas/\#/) 


\section{Hasil dan Pembahasan}

\subsection{Hasil}

Tools GIS yang dijalankan oleh perangkat HEC-HMS 4.4 saat proses delineasi DAS secara berurutan adalah sebagai berikut : 1) preprocess sinks; 2) preprocess drainage; 3) identify streams; 4) break point manager; 5) Delineate elements. Proses pengisian cekungan (preprocess sink) merupakan proses pengisian daerah cekungan berdasarkan data DEM. Hasil keluaran dari proses pengisian cekungan adalah sink fill dan sink location yang dapat dilihat pada Gambar 4.a. Proses dilanjutkan ke tahapan preprocess drainage, proses ini melakukan identifikasi arah aliran (flow direction) dan akumulasi dari setiap arah aliran (flow accumulation) seperti terlihat pada Gambar 4.b dan Gambar 4.c. Selanjutnya proses identifikasi aliran (identify streams) dijalankan berdasarkan hasil akumulasi aliran dari proses pengisian cekungan. Proses identify streams menghasilkan raster aliran sungai (streams) seperti pada Gambar 4.d. Proses akhir sebelum perangkat HEC-HMS 4.4 melakukan delineasi DAS adalah mengidentifikasi titik keluaran (outlet) yang dijalankan melalui perintah break point manager. Pemilihan titik outlet dalam menentukan batas suatu DAS sebaiknya berada pada lokasi penempatan Automatic Water Level Recorder (AWLR) atau pos duga air. Penelitian kali ini posisi outlet berada pada titik pengamatan tinggi muka air Sungai Tojo pada koordinat $01^{\circ} 17^{\prime} 15^{\prime \prime}$ LS dan $121^{\circ} 14^{\prime} 18^{\prime}$ BT. Setelah HEC-HMS mengidentifikasi titik outlet seperti terlihat pada Gambar 4.e, kemudian proses dilanjutkan pada penentuan batas DAS melalui perintah delineate elements, yang pada penelitian ini menghasilkan 25 sub-DAS seperti terlihat pada gambar 4.f. Secara umum gambaran proses dan file keluaran dari setiap tahapan delineasi DAS HEC-HMS 4.4 dapat dilihat pada Tabel 1 dan Gambar 4.

Tabel 1. Tahapan dan hasil delineasi DAS HEC-HMS 4.4

\begin{tabular}{clc}
\hline No & \multicolumn{1}{c}{ Proses } & File keluaran proses \\
\hline 1 & Preprocess Sinks & Sink fill dan sink location \\
2 & Preprocess drainage & Flow direction dan flow accumulation \\
3 & Identify streams & Streams \\
4 & Breakpoint manager & Lokasi outlet \\
5 & Delineate elements & Batas-batas SubDAS \\
\hline
\end{tabular}

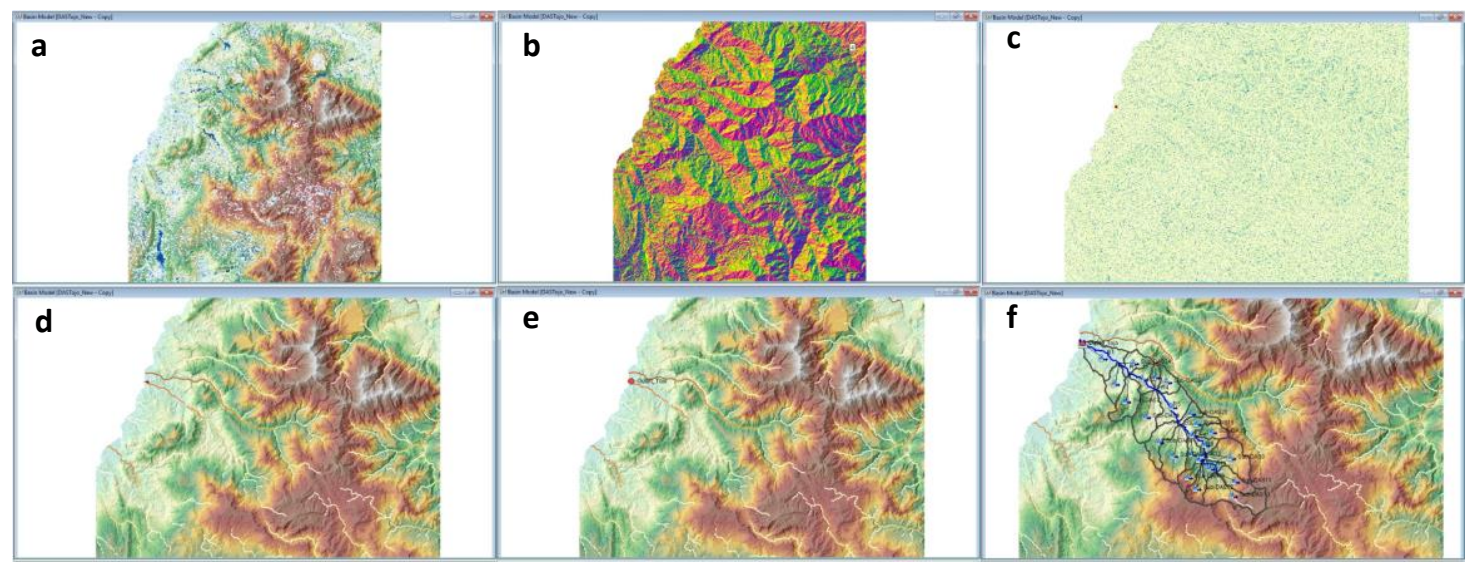

Gambar 4. Hasil keluaran setiap proses Delineasi DAS menggunakan perangkat HEC-HMS 4.4; a. sink location; b. flow direction; c. flow accumulation; d. streams; e. outlet; f. subDAS 
Untuk membandingkan kualitas tools GIS pada HEC HMS 4.4, maka peneliti juga melakukan proses delineasi DAS menggunakan perangkat GIS lainnya yakni QGIS 3.16. Secara garis besar tahapan proses delineasi DAS menggunakan perangkat QGIS 3.16 terdiri dari proses fill sinks menggunakan metode wang and liu, Stahler order dan upslope area. Hasil keluaran dari masing-masing proses berupa file raster yang penamaannya dapat ditentukan oleh pengguna. Proses fill sinks akan menghasilkan raster filleddem dan flowdir seperti terlihat pada Gambar 5.a dan Gambar 5.b. Raster filleddem selanjutnya digunakan pada proses penentuan orde sungai melalui proses Stahler order untuk selanjutnya akan mengidentifikasi jaringan sungai. Raster keluaran dari proses Stahler order dapat dilihat pada Gambar 5.c. Pada Gambar 5.c raster keluaran Stahler order arah aliran sungai belum terlihat, sehingga dilakukan proses identifikasi arah aliran sungai (streams), menggunakan raster calculator. Setelah melalui proses raster calculator arah aliran sungai terlihat lebih jelas seperti Gambar 5.d. Agar terlihat lebih jelas maka raster arah aliran (streams) dikoncersi menjadi data vektor seperti terlihat pada gambar 5.e. Proses kemudian dilanjutkan dengan mengidentifikasi semua komponen hidrologi dari hulu hingga ke hilir pada proses upslope. Proses upslope menganalisis setiap nilai pixel dari raster filleddem. Target identifikasi proses upslope adalah koordinat titik outlet dari DAS. Titik outlet yang digunakan sama dengan titik outlet yang digunakan untuk mengidentifikasi batas DAS menggunakan HEC-HMS 4.4. Proses upslope merupakan proses yang mengidentifikasi batas DAS seperti terlihat pada Gambar 5.f. Selanjutnya dilakukan finalisasi untuk membuat peta DAS dengan tampilan yang menarik dengan mengkonversi raster stream.tif dan upslope.tif menjadi polygon menggunakan perintah raster conversion. Proses delineasi DAS pada QGIS 3.16 dapat dilihat pada Gambar 5.
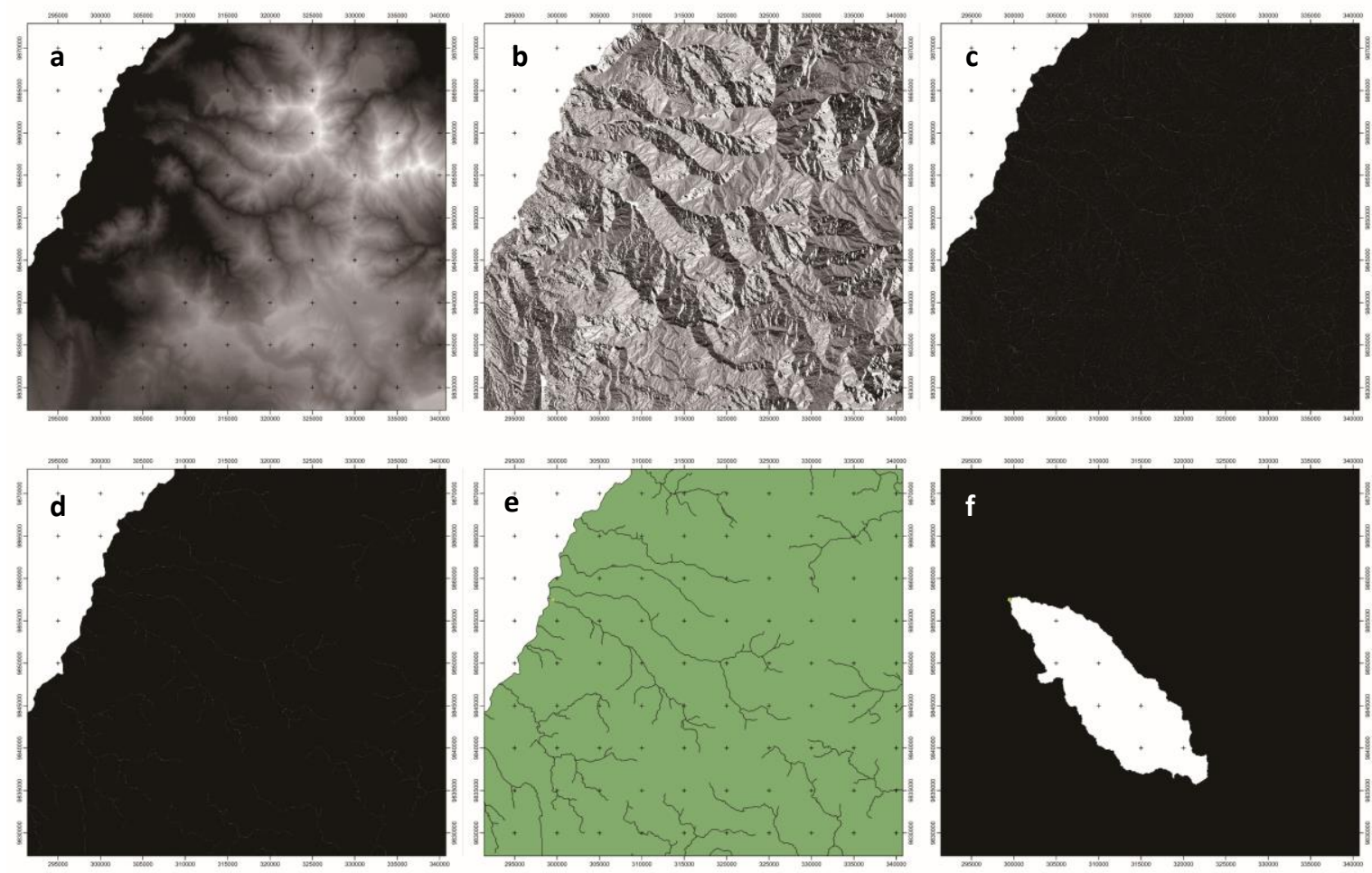

Gambar 5. Hasil keluaran setiap proses Delineasi DAS QGIS 3.16; a. filleddem; b. flowdir; c. Stahler order; d. stream raster; e. stream vector; f. Upslope 


\subsection{Pembahasan}

Dari hasil kajian terhadap setiap proses delineasi DAS menggunakan perangkat HEC-HMS 4.4 dan QGIS 3.16 diperoleh gambaran bahwa batas DAS yang dihasilkan menggunakan perangkat HECHMS 4.4 sama dengan batas DAS yang dihasilkan perangkat QGIS 3.16 maupun perangkat GIS lainnya. Pada penelitian ini, batas DAS Tojo yang dihasilkan program HEC-HMS 4.4 dan QGIS 3.16 terdapat kesamaan bentuk, akan tetapi terdapat sedikit perbedaan garis batas DAS di beberapa bagian jika dilakukan pembesaran (zoom) seperti terlihat pada Gambar 6. Sedangkan untuk komponen hidrologi streams atau aliran sungai yang dihasilkan perangkat HEC-HMS 4.4 ini terdapat sedikit perbedaan posisi. Perbedaan arah aliran sungai keluaran HEC-HMS 4.4 dan QGIS 3.16 dapat dilihat pada Gambar 7.

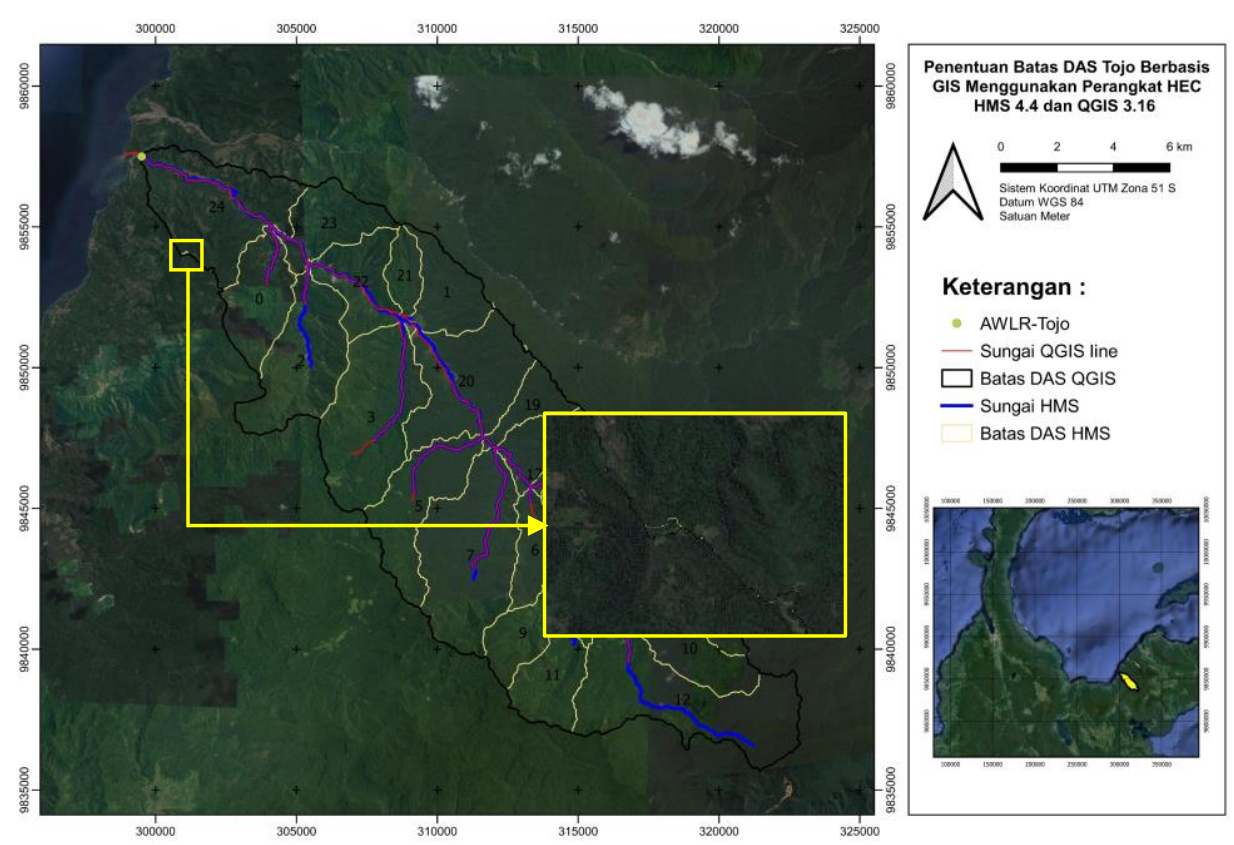

Gambar 6. Perbedaan batas DAS HEC-HMS 4.4 dan QGIS 3.16

(sumber : Pengolahan Data, 2021)

Seperti pada perangkat-perangkat GIS pada umumnya ketelitian hasil dari setiap proses sangat bergantung dari algoritma yang digunakan pada saat perangkat melakukan pemrosesan data serta perintah masukan dari pengguna. QGIS dalam melakukan proses pengisian cekungan (fill sinks) menggunakan metode wang and liu (van der Skwat, 2018) sedangkan HEC-HMS tidak mencantumkan metode dari setiap proses yang dijalankan dalam melakukan delineasi batas DAS.

Perbedaan signifikan dari kedua perangkat ini juga terlihat pada identifikasi aliran atau identify streams. HEC-HMS cenderung tertutup dengan tidak menampilkan metode identifikasi aliran, akan tetapi dalam proses identifikasi aliran pengguna diarahkan oleh HEC-HMS untuk memasukkan nilai luas daerah tangkapan di sekitar aliran yang nantinya akan dikategorikan oleh HEC-HMS sebagai aliran sungai. Untuk identifikasi aliran QGIS menggunakan metode Stahler dimana QGIS mengidentifikasi orde-orde dari setiap arah aliran (flow direction) yang dihasilkan dari proses sebelumnya. Selanjutnya, pengguna akan diminta mengidentifikasi aliran yang dianggap sebagai aliran sungai dengan menggunakan raster calculator. Aliran sungai inilah yang nantinya akan dijadikan dasar penentuan batas DAS oleh QGIS. 


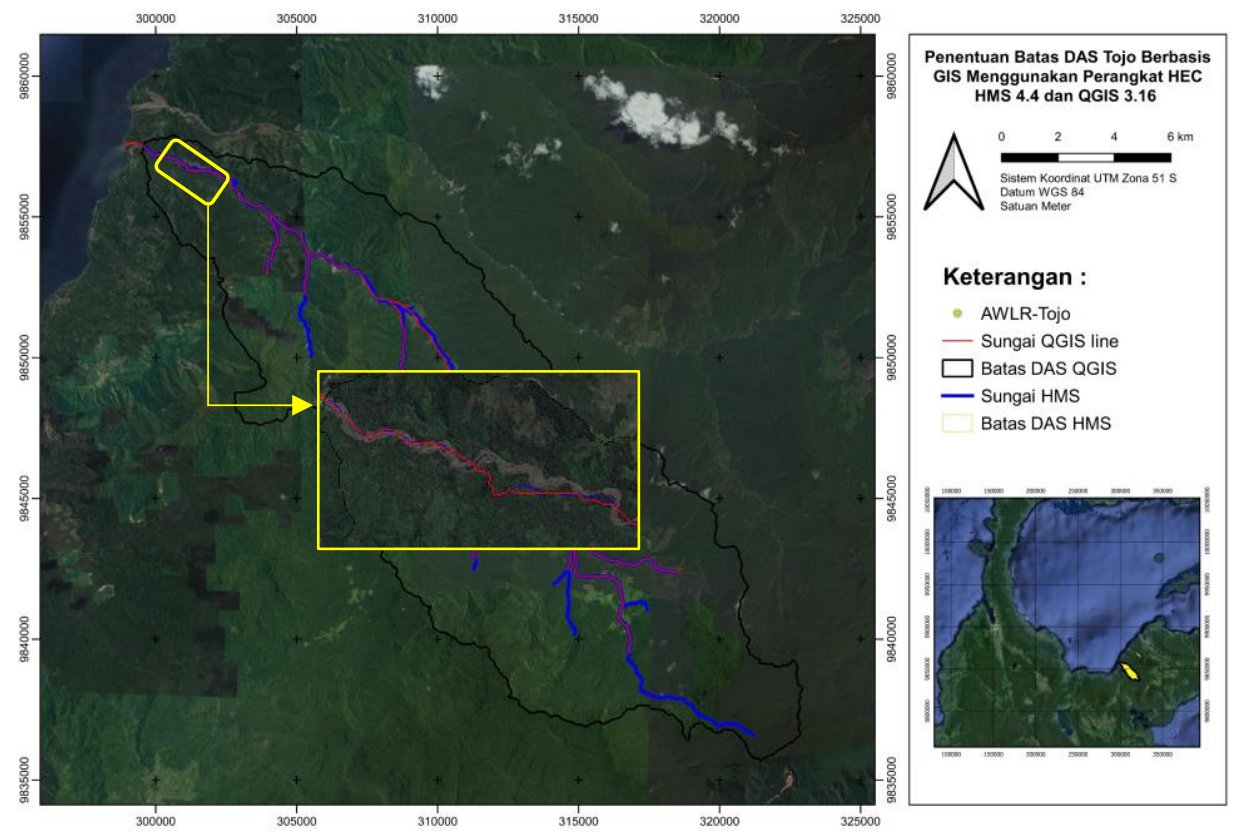

\section{Gambar 7. Perbedaan streams (posisi aliran) HEC-HMS 4.4 dan QGIS 3.16}

Selanjutnya pada proses analisis batas DAS juga terdapat perbedaan dari kedua perangkat ini dimana HEC-HMS menentukan batas DAS dengan mengidentifikasi daerah tangkapan hujan pada proses identifikasi aliran dengan membatasi analisis daerah tangkapan pada titik breakpoint atau outlet. QGIS dalam menganalisis batas DAS melalui proses upslope dengan mengidentifikasi lereng-lereng yang menyumbang aliran air menuju titik tertentu (outlet). Perbedaan hasil analisis batas DAS juga dapat diidentifikasi melalui perbedaan luas DAS dari masing-masing perangkat. Terdapat 25 sub DAS yang teridentifikasi oleh perangkat HEC-HMS 4.4 setelah melalui proses delineate elements, masing-masing luas sub DAS dapat dilihat pada Tabel 2.

Tabel 2. Luas Sub DAS hasil delineasi DAS perangkat HEC-HMS 4.4

\begin{tabular}{cccccc}
\hline Basin id & Nama & Luas $\left.\mathbf{( k m}^{\mathbf{2}}\right)$ & Basin id & Nama & Luas $\left.\mathbf{( k m}^{\mathbf{2}}\right)$ \\
\hline 0 & Sub-DAS1 & 8,377065 & 13 & Sub-DAS14 & 0,478638 \\
1 & Sub-DAS2 & 6,580717 & 14 & Sub-DAS15 & 4,492046 \\
2 & Sub-DAS3 & 12,92752 & 15 & Sub-DAS16 & 0,189501 \\
3 & Sub-DAS4 & 16,89374 & 16 & Sub-DAS17 & 4,472576 \\
4 & Sub-DAS5 & 6,274189 & 17 & Sub-DAS18 & 0,300015 \\
5 & Sub-DAS6 & 10,67928 & 18 & Sub-DAS19 & 6,752342 \\
6 & Sub-DAS7 & 5,323219 & 19 & Sub-DAS20 & 3,694824 \\
7 & Sub-DAS8 & 18,59648 & 20 & Sub-DAS21 & 14,24627 \\
8 & Sub-DAS9 & 17,34647 & 21 & Sub-DAS22 & 3,178494 \\
9 & Sub-DAS10 & 5,573069 & 22 & Sub-DAS23 & 7,393944 \\
10 & Sub-DAS11 & 7,812302 & 23 & Sub-DAS24 & 7,137719 \\
11 & Sub-DAS12 & 7,429073 & 24 & Sub-DAS25 & 15,9849 \\
12 & Sub-DAS13 & 20,44826 & Total Luas $\left.\mathbf{( k m}^{\mathbf{2}}\right)$ & & $\mathbf{2 1 2 , 5 8 3}$ \\
\hline
\end{tabular}

Luas total dari 25 sub DAS Tojo yang dihasilkan perangkat HEC-HMS 4.4 adalah 212,5830 $\mathrm{km}^{2}$ sedangkan luas DAS yang dihasilkan oleh perangkat QGIS 3.16 adalah 212,5404 $\mathrm{km}^{2}$. QGIS tidak membagi batas DAS menjadi batas Sub-Sub DAS seperti yang dilakukan HEC-HMS. Pada penelitian 
lainnya, luas DAS Tojo adalah $21275 \mathrm{Ha}$ atau $212,75 \mathrm{~km}^{2}$, hasil ini diperoleh berdasarkan analisis SWAT (Soil and Water Analysis Tools) pada tools ArcGIS dengan menggunakan data masukan utama (DEM) yang bersumber dari data Digital Elevation Model Nasional (DEMNAS) BIG (Amiruddin, 2020).

\section{Kesimpulan}

Secara umum proses-proses yang dijalankan tools GIS HEC-HMS 4.4 saat melakukan delineasi DAS lebih mudah dipahami dan dijalankan dibandingkan dengan proses-proses delineasi DAS menggunakan perangkat QGIS 3.16. Perangkat HEC-HMS 4.4 juga dapat menghasilkan batas DAS dengan sangat baik, dimana hasil delineasi DAS HEC-HMS 4.4 sangat mirip dengan hasil delineasi batas DAS perangkat QGIS 3.16. Perbedaan luas DAS dari masing-masing perangkat adalah : HECHMS 4.4 dengan luasan 212,583 km²; QGIS 3.16 dengan luasan 212,5404 km². Karena memberikan hasil yang sangat baik, maka penulis merekomendasikan penggunaan tool GIS HEC-HMS 4.4 ini untuk dapat digunakan dalam menentukan batas DAS saat melakukan penelitian-penelitian bidang sumber daya air.

\section{Ucapan Terima Kasih}

Ucapan terima kasih kami sampaikan kepada Badan Informasi Geospasial (BIG) atas keterbukaan informasi terkait data Digital Elevation Model National (DEMNAS) yang dengan mudah diperoleh melalui halaman https://tanahair.indonesia.go.id/demnas/\#/demnas.

\section{Daftar Pustaka}

Al Amin, M.B., Toyfur, M.F., Fransiska, W., Marlina, \& A. 2020. Delineasi DAS dan Elemen Model Hidrologi Menggunakan HEC-HMS Versi 4.4. Cantilever: Jurnal Penelitian Dan Kajian Bidang Teknik Sipil. 9(1). 33-38.

Amiruddin, A. 2020. Analisa Debit Banjir Rancangan DAS Tojo Metode HSS ITB. Borneo Engineering : Jurnal Teknik Sipil. 4(2). 126-137.

Badan Informasi Geospasial. DEMNAS Seamless Digital Elevation Model (DEM) dan Batimetri Nasional. https://tanahair.indonesia.go.id/demnas/\#/ diakses : 21 Mei 2020

Bhatt, J.P., \& Pandya, P. 2014. Application of HEC-GeoHMS as a Tool of Hydrologic Modeling in the Field of Water Resources Engineering. IJSRD. 1(11). 2486-2488.

Indarto. 2016. Hidrologi Metode Analisis dan Tool Interpretasi Hidrograf Aliran Sungai. Bumi Aksara. Jakarta.

Gunawan, G. 2011. Deliniasi DAS Berbasis Sistem Informasi Geografis dalam Rangka Mendukung Pengelolaan DAS Terpadu. Inersia: Jurnal Teknik Sipil. 3(1). 7-15.

Hasna, NR., Setiawan, A., Parhusip, HA. 2018. Penentuan Lokasi Lumbung Pangan Berdasarkan Gravity Location Models Dengan Koordinat UTM di Provinsi Maluku Utara. Jurnal Sains dan Edukasi Sains. 1(2). 7-16

Purwono, N. 2018. Teknik Filtering Model Elevasi Digital (DEM) untuk Delineasi Batas Daerah Aliran Sungai. Prosiding Seminar Nasional Geografi UMS IX. Surakarta.

QGIS Project. 2021. QGIS Training Module. 
Strapazan, C., Petrut, M. 2017. Application of Arc Hydro And HEC-HMS Model Techniques for Runoff Simulation in The Headwater Areas of Covasna Watershed (Romania). Geographia Technica. 12(1). 95-107.

Triatmodjo, B. 2013. Hidrologi Terapan. Beta Offset. Yogyakarta.

USACE. 2021. HEC-HMS Users Manual. US-Army Corps of Engineers. Hydrologic Engineering Center. St. Davis

Van der Skwat, H. 2018. QGIS and Open Data for Hydrological Application - Exercise Manual. IHE Delft.

Pemerintah Kabupaten Tojo Una Una. 2020. Gambaran Umum. www.tojounauna.go.id/index.php/potensi-daerah/gambaran-umum 